\title{
Viewpoint \\ The paradox of ventilator-associated pneumonia prevention measures
}

\author{
Michael Klompas ${ }^{1,2}$
}

\author{
${ }^{1}$ Infection Control Department, Brigham and Women's Hospital and Harvard Medical School, 75 Francis Street, Boston, MA 02115, USA \\ 2Department of Population Medicine, Harvard Medical School and Harvard Pilgrim Health Care, 133 Brookline Avenue, Boston, MA 02215, USA
}

Corresponding author: Michael Klompas, mklompas@partners.org

Published: 15 October 2009

Critical Care 2009, 13:315 (doi:10.1186/cc8036)

This article is online at http://ccforum.com/content/13/5/315

(C) 2009 BioMed Central Ltd

\begin{abstract}
There is a striking paradox in the literature supporting high-profile measures to reduce ventilator-associated pneumonia (VAP): many studies show significant reductions in VAP rates but almost none show any impact on patients' duration of mechanical ventilation, length of stay in the intensive care unit and hospital, or mortality. The paradox is largely attributable to lack of specificity in the VAP definition. The clinical and microbiological criteria for VAP capture a population of patients with an array of conditions that range from serious to benign. Many of the benign events are manifestations of bacterial colonization superimposed upon pulmonary edema, atelectasis, or other non-infectious processes. VAP prevention measures that work by decreasing bacterial colonization preferentially lower the frequency of these mislabelled, more benign events. In addition, misclassification obscures detection of an impact of prevention measures on bona fide pneumonias. Together, these effects create the possibility of the paradox where a prevention measure may have a large impact on VAP rates but minimal impact on patients' outcomes. The paradox makes changes in VAP rates alone an unreliable measure of whether VAP prevention measures are truly beneficial to patients and behooves us to measure their impact on patient outcomes before advocating their adoption.
\end{abstract}

\section{The paradox}

Hospitals around the world are striving to reduce their rates of ventilator-associated pneumonia (VAP) in order to improve patient outcomes and minimize costs. Professional societies, legislators, quality improvement advocates, and medical product manufacturers are promoting an increasing array of interventions to reduce VAP rates. These include regular oral care, elevation of the head of the bed, continuous aspiration of subglottic secretions, silver-coated endotracheal tubes, and many other initiatives. Some jurisdictions now mandate hospitals to report adherence with a subset of these 'process measures'. Review of the literature supporting these interventions, however, reveals a striking paradox: each of these strategies dramatically reduces VAP rates but almost none has any impact on patients' duration of mechanical ventilation, hospital length of stay, or mortality (Table 1).

Regular oral care with chlorhexidine, for example, reduces VAP rates by up to $37 \%$ to $66 \%$ but has no impact on duration of mechanical ventilation, intensive care unit (ICU) or hospital length of stay, or mortality [1-4]. Likewise, elevation of the head reduces the VAP rate by $78 \%$ [5], continuous aspiration of subglottic secretions reduces VAP rates by $50 \%$ to $55 \%[6,7]$, and silver-coated endotracheal tubes decrease VAP rates by $36 \%$ [8]. None of these investigations, though, showed an impact on patients' outcomes. Many of these studies were not primarily powered to detect a difference in length of stay or mortality, but it is striking that they did not even show trends toward improvements in these outcomes regardless of whether considered alone or in metaanalyses that included thousands of patients $[4,9,10]$. The failure of these studies to detect an impact on patient outcomes is conspicuous since the balance of research does show that VAP doubles the risk of dying and increases intensive care length of stay by a mean of 6 days [11].

\section{The explanation}

The source of this paradox lies in the ambiguity and inaccuracy inherent in VAP diagnosis. VAP is typically defined as the presence of fever, abnormal white blood cell count, purulent sputum, and new radiographic infiltrates. On intensive investigation, however, only a fraction of patients with these signs truly have histological pneumonia [12]. Instead, up to two thirds of people who fulfill this definition have one or more alternative conditions that range from relatively benign, such as atelectasis and tracheobronchitis, to severe, such as acute respiratory distress syndrome or pulmonary infarction $[13,14]$. 
Table 1

Randomized controlled trials of interventions to prevent ventilator-associated pneumonia

\begin{tabular}{|c|c|c|c|c|c|c|}
\hline & \multicolumn{6}{|c|}{ Impact on } \\
\hline & Subjects & VAP rates & Ventilator LOS & ICU LOS & Hospital LOS & Mortality \\
\hline \multicolumn{7}{|l|}{ Elevation of the head of the bed } \\
\hline Drakulovic, et al., 1999 [5] & 86 & $78 \% \downarrow$ & NS & NS & - & NS \\
\hline van Nieuwenhoven, et al., 2006 [46] & 221 & NS & NS & NS & - & NS \\
\hline \multicolumn{7}{|l|}{ Oral care } \\
\hline \multicolumn{7}{|l|}{ Chlorhexidine } \\
\hline DeRiso, et al., 1996 [40] & 353 & NS & NS & - & NS & $80 \% \downarrow$ \\
\hline Fourrier, et al., 2000 [1] & 60 & $66 \% \downarrow$ & NS & NS & - & NS \\
\hline Genuit, et al., 2001 [2] & 95 & $37 \% \downarrow$ & NS & NS & NS & - \\
\hline Houston, et al., 2002 [47] & 561 & NS & NS & - & - & - \\
\hline Fourrier, et al., 2005 [48] & 228 & NS & NS & NS & - & NS \\
\hline Koeman, et al., 2006 [3] & 257 & NS & NS & NS & NS & NS \\
\hline Segers, et al., 2006 [49] & 954 & $50 \% \downarrow$ & - & NS & $8 \% \downarrow$ & NS \\
\hline Tantipong, et al., 2008 [50] & 207 & NS & - & - & - & NS \\
\hline Chan, et al., 2007 [4] (meta-analysis) & 2,144 & $44 \% \downarrow$ & NS & NS & - & NS \\
\hline \multicolumn{7}{|l|}{ Oral topical antibiotics } \\
\hline Laggner, et al., 1994 [51] (gentamicin) & 67 & NS & NS & - & - & NS \\
\hline $\begin{array}{l}\text { Bergmans, et al., } 2001 \text { [52] } \\
\text { (gentamicin, colistin, vancomycin) }\end{array}$ & 226 & $57 \%-68 \% \downarrow$ & NS & NS & NS & NS \\
\hline Kollef, et al., 2006 [53] (iseganan) & 709 & NS & - & - & - & NS \\
\hline Chan, et al., 2007 [4] (meta-analysis) & 1,098 & NS & NS & NS & - & NS \\
\hline $\begin{array}{l}\text { de Smet, et al., } 2009 \text { [31] } \\
\text { (tobramycin, colistin, amphotericin B) }\end{array}$ & 3,894 & - & NS & NS & NS & $14 \% \downarrow$ \\
\hline \multicolumn{7}{|l|}{ Deep vein thrombosis prophylaxis } \\
\hline Samama, et al., 1999 [54] & 1,102 & - & - & - & - & NS \\
\hline Fraisse, et al., 2000 [55] & 223 & - & - & - & - & NS \\
\hline Leizorovicz, et al., 2004 [56] & 3,706 & - & - & - & - & NS \\
\hline Mahé, et al., 2005 [57] & 2,474 & - & - & - & - & NS \\
\hline \multicolumn{7}{|l|}{ Stress ulcer prophylaxis } \\
\hline Prod'hom, et al., 1994 [58] & 248 & NS & - & - & - & NS \\
\hline Bonten, et al., 1995 [59] & 141 & NS & - & - & NS & NS \\
\hline Yildizdas, et al., 2002 [60] & 160 & NS & - & - & - & NS \\
\hline Kantorova, et al., 2004 [61] & 287 & NS & NS & NS & - & NS \\
\hline Cook, et al., 1996 [10] (meta-analysis) & 7,218 & NS & - & - & - & NS \\
\hline \multicolumn{7}{|l|}{ Continuous aspiration of subglottic secretions } \\
\hline Valles, et al., 1995 [6] & 153 & $37 \% \downarrow$ & - & NS & - & NS \\
\hline Kollef, et al., 1999 [62] & 343 & $39 \% \downarrow$ & NS & NS & NS & NS \\
\hline Smulders, et al., 2002 [63] & 150 & $75 \% \downarrow$ & NS & NS & NS & NS \\
\hline Lorente, et al., 2007 [64] & 280 & $64 \% \downarrow$ & NS & NS & - & NS \\
\hline Bouza, et al., 2008 [39] & 690 & NS & NS & NS & NS & NS \\
\hline \multicolumn{7}{|l|}{ Silver-coated endotracheal tubes } \\
\hline Kollef, et al., 2008 [8] & 2,003 & $36 \% \downarrow$ & NS & NS & NS & NS \\
\hline
\end{tabular}

ICU, intensive care unit; LOS, length of stay; NS, not statistically significant; VAP, ventilator-associated pneumonia; Ventilator LOS, duration of mechanical ventilation. 
The addition of microbiological criteria does little to improve accuracy. Many studies define VAP as the presence of greater than 1,000 colony-forming units per milliliter on culture of bronchoalveolar lavage fluid. This definition is attractive because it is objective, but unfortunately it is no more accurate than clinical criteria alone [15]. The sensitivity and specificity of this definition relative to a histological gold standard are only $50 \%-70 \%$ and $40 \%-95 \%$, respectively [16-19]. False positives are due to contamination of the lavage specimen by bacteria colonizing the patient's endotracheal tube and upper airway. This effect is particularly marked in patients with prolonged ventilation. False negatives arise from the failure to sample the correct lung segment, insufficient bacterial growth to cross the quantitative threshold, and damping of bacterial growth by prior antibiotic exposure.

Much of VAP misdiagnosis stems from bacterial colonization superimposed upon non-infectious pulmonary processes such as fluid shifts, barotrauma, atelectasis, inflammatory reactions, and exacerbations of patients' underlying lung disease. These factors wax and wane in ways that are difficult to discern at the bedside, leading to the transient appearance of clinical syndromes suggestive of VAP. As often as not, these processes spontaneously resolve in short order without definitive therapy. Clinical trials for early empiric treatment of suspected VAP followed by reassessment 48 to 72 hours later hint at this process. In many patients, the VAP syndrome is no longer present on reassessment and antibiotics can safely be stopped without discernible impact on patient outcomes [20-22].

Mislabelling benign events as VAP creates bias if prevention measures preferentially affect the more benign disorders over the more serious disorders present within the spectrum of conditions that look like VAP. This is particularly likely in studies that use a microbiological definition of VAP to assess interventions that work by decreasing bacterial colonization of the endotracheal tube. For example, the NASCENT (North American Silver-Coated Endotracheal Tube) study of silver-coated endotracheal tubes compared with conventional endotracheal tubes found a statistically significant 36\% reduction in microbiologically confirmed VAP yet no difference in the rate of physician-suspected VAP $(26 \%$ versus $31 \%, P=0.39)$ or patients with radiographic infiltrates and suggestive clinical signs $(53 \%$ versus $56 \%, P=0.74)$ [8]. This discrepancy between rates of microbiologically defined VAP versus clinically defined VAP suggests that silver-coated tubes preferentially decrease colonization rather than infection. This is further borne out by identical durations of mechanical ventilation, ICU stay, hospital stay, and mortality between patients with silvercoated versus conventional tubes. Other interventions that decrease microbial colonization, such as oral chlorhexidine and continuous aspiration of subglottic secretions, might also be subject to this bias.
Mislabelling benign events as VAP further contributes to the paradox by obscuring faint but true signals from bona fide pneumonias. Some interventions designed to prevent VAP may well reduce the frequency of bona fide pneumonias (and truly improve outcomes for this subset of patients), but the plethora of alternative conditions captured by the VAP definition dilute the signal coming from the subset of patients with true pneumonias. Generally low event rates in both the intervention and control groups of many studies compound the challenge of detecting significant impacts on outcomes. These effects may also explain some of the conflicting results in studies evaluating the attributable mortality of VAP: the failure of some studies to detect an impact on mortality [2326] despite a statistically significant impact in other studies [27-29] and on meta-analysis [11] may be due to damping of the 'true' VAP morbidity signal by misclassifying relatively benign conditions as VAP. Alternatively, VAP may be more of a marker for severity of illness in intubated patients rather than an independent source of morbidity in and of itself. Either way, the failure of multiple clinical trials to detect an impact of VAP prevention measures on patient outcomes suggests that the net benefit of these interventions on the population level is small.

\section{The implication}

The near impossibility of accurate VAP diagnosis compels us to exert great caution when interpreting trial data and hospital surveillance data showing decreases in VAP rates. Lower rates in the intervention arm of clinical trials may reflect disproportionate decreases in benign mimickers of VAP rather than VAP itself. Similarly, observational reports of markedly reduced VAP rates in some hospitals may reflect measurement artefact more than true reductions in serious disease [14]. Before advocating their adoption, we need to see that new interventions and quality improvement programs impact meaningful outcomes rather than just VAP rates.

Likewise, legislators considering mandatory reporting of VAP prevention process measures should consider their impact on outcomes before compelling implementation. Due to the inaccuracy and ambiguity in surveillance definitions, many jurisdictions have shied away from requiring VAP reporting $[14,30]$. It will be a great irony if these jurisdictions now compel hospitals to report VAP prevention process measures validated by studies that used the same imperfect VAP definitions to prove their value yet failed to show any impact on patient outcomes.

Clinicians and patients can take heart that some interventions have been shown to improve hard outcomes and do merit adoption. Selective oropharyngeal decontamination reduces ICU patients' mortality [31]. Likewise, daily sedative interruptions and daily assessments of readiness to extubate consistently reduce patients' duration of mechanical ventilation and possibly lower mortality (Table 2) [32-38]. Other 


\begin{tabular}{|c|c|c|c|c|c|c|}
\hline & \multicolumn{6}{|c|}{ Impact on } \\
\hline & Subjects & VAP rates & Ventilator LOS & ICU LOS & Hospital LOS & Mortality \\
\hline \multicolumn{7}{|l|}{ Daily spontaneous breathing trial } \\
\hline Esteban, et al., 1995 [35] & 546 & - & $\begin{array}{c}40 \% \downarrow \\
(-2 \text { days })\end{array}$ & - & - & - \\
\hline Ely, et al., 1996 [34] & 300 & - & $\begin{array}{c}25 \% \downarrow \\
\text { (-1.5 days) }\end{array}$ & NS & NS & NS \\
\hline Kollef, et al., 1997 [33] & 357 & - & $\begin{array}{c}20 \% \downarrow \\
\text { (-0.4 days) }\end{array}$ & - & NS & NS \\
\hline Marelich, et al., 2000 [32] & 385 & NS & $\begin{array}{c}45 \% \downarrow \\
\text { (-2.3 days) }\end{array}$ & - & - & NS \\
\hline Lellouche, et al., 2006 [36] & 144 & NS & $\begin{array}{c}38 \% \downarrow \\
(-4.5 \text { days })\end{array}$ & $\begin{array}{c}22.6 \% \downarrow \\
\text { (-3.5 days) }\end{array}$ & NS & NS \\
\hline \multicolumn{7}{|l|}{ Daily sedative interruption } \\
\hline $\begin{array}{l}\text { Kress, et al., } 2000 \text { [37] and } \\
\text { Schweickert, et al., 2004 [65] }\end{array}$ & 128 & NS & $\begin{array}{c}33 \% \downarrow \\
\text { (-2.4 days) }\end{array}$ & $\begin{array}{c}35 \% \downarrow \\
\text { (-3.5 days) }\end{array}$ & NS & NS \\
\hline \multicolumn{7}{|c|}{ Daily spontaneous breathing trial and sedative interruption } \\
\hline Girard, et al., 2008 [38] & 336 & - & $\begin{array}{c}19 \% \downarrow \\
\text { (-3.1 days) }\end{array}$ & $\begin{array}{c}29 \% \downarrow \\
\text { (-3.8 days) }\end{array}$ & $\begin{array}{c}22 \% \downarrow \\
\text { (-4.3 days) }\end{array}$ & $\begin{array}{c}28 \text { days: NS } \\
1 \text { year: } 32 \% \downarrow\end{array}$ \\
\hline
\end{tabular}

ICU, intensive care unit; LOS, length of stay; NS, no statistically significant impact; VAP, ventilator-associated pneumonia; Ventilator LOS, duration of mechanical ventilation.

VAP prevention measures may decrease antibiotic usage $[39,40]$ but this outcome has not yet been widely studied.

There is also tentative evidence that combining interventions into bundles may impact patient outcomes even when the component interventions alone do not. Ventilator bundles typically include elevating the head of the bed, stress ulcer prophylaxis, thromboembolism prophylaxis, and a daily weaning assessment. None of these measures in isolation has been shown to decrease patients' length of stay, yet three centers implementing these measures as a bundle reported shorter ICU lengths of stay [41-43] and a fourth center found shorter hospital length of stay [44] compared with historical rates. These studies, while promising, need to be interpreted with great caution since they suffer many methodological limitations, including the use of historical rather than concurrent controls [45].

For too long, we have accepted VAP as a surrogate marker for the outcomes we really care about, namely patients' duration of mechanical ventilation, hospital length of stay, and mortality. The disparity between prevention measures' impact on VAP rates and their lack of impact on patient outcomes underscores the inadequacy of VAP as a surrogate marker. We need to directly assess the impact of VAP prevention measures on patient outcomes before advocating or compelling their adoption.

\section{Competing interests}

The author declares that they have no competing interests.

\section{References}

1. Fourrier $F$, Cau-Pottier E, Boutigny $H$, Roussel-Delvallez $M$, Jourdain M, Chopin C: Effects of dental plaque antiseptic decontamination on bacterial colonization and nosocomial infections in critically ill patients. Intensive Care Med 2000, 26:12391247.

2. Genuit T, Bochicchio G, Napolitano LM, McCarter RJ, Roghman MC: Prophylactic chlorhexidine oral rinse decreases ventilator-associated pneumonia in surgical ICU patients. Surg Infect (Larchmt) 2001, 2:5-18.

3. Koeman $M$, van der Ven AJ, Hak E, Joore HC, Kaasjager $K$, de Smet AG, Ramsay G, Dormans TP, Aarts LP, de Bel EE, Hustinx WN, van der Tweel I, Hoepelman AM, Bonten MJ: Oral decontamination with chlorhexidine reduces the incidence of ventilator-associated pneumonia. Am J Respir Crit Care Med 2006, 173:1348-1355.

4. Chan EY, Ruest A, Meade MO, Cook DJ: Oral decontamination for prevention of pneumonia in mechanically ventilated adults: systematic review and meta-analysis. BMJ 2007, 334: 889.

5. Drakulovic MB, Torres A, Bauer TT, Nicolas JM, Nogue S, Ferrer $M$ : Supine body position as a risk factor for nosocomial pneumonia in mechanically ventilated patients: a randomised trial. Lancet 1999, 354:1851-1858.

6. Valles J, Artigas A, Rello J, Bonsoms N, Fontanals D, Blanch L, Fernandez R, Baigorri F, Mestre J: Continuous aspiration of subglottic secretions in preventing ventilator-associated pneumonia. Ann Intern Med 1995, 122:179-186.

7. Mahul P, Auboyer C, Jospe R, Ros A, Guerin C, el Khouri Z, Galliez M, Dumont A, Gaudin O: Prevention of nosocomial pneumonia in intubated patients: respective role of mechanical subglottic secretions drainage and stress ulcer prophylaxis. Intensive Care Med 1992, 18:20-25. 
8. Kollef MH, Afessa B, Anzueto A, Veremakis C, Kerr KM, Margolis BD, Craven DE, Roberts PR, Arroliga AC, Hubmayr RD, Restrepo MI, Auger WR, Schinner R; NASCENT Investigation Group: Silver-coated endotracheal tubes and incidence of ventilatorassociated pneumonia: the NASCENT randomized trial. JAMA 2008, 300:805-813.

9. Dezfulian C, Shojania K, Collard HR, Kim HM, Matthay MA, Saint $\mathrm{S}$ : Subglottic secretion drainage for preventing ventilatorassociated pneumonia: a meta-analysis. $A m$ J Med 2005, 118: 11-18.

10. Cook DJ, Reeve BK, Guyatt GH, Heyland DK, Griffith LE, Buckingham $L$, Tryba $M$ : Stress ulcer prophylaxis in critically ill patients. Resolving discordant meta-analyses. JAMA 1996, 275:308-314

11. Safdar N, Dezfulian C, Collard HR, Saint S: Clinical and economic consequences of ventilator-associated pneumonia: a systematic review. Crit Care Med 2005, 33:2184-2193.

12. Marquette $\mathrm{CH}$, Copin $\mathrm{MC}$, Wallet $F$, Neviere $\mathrm{R}$, Saulnier $F$, Mathieu D, Durocher A, Ramon P, Tonnel AB: Diagnostic tests for pneumonia in ventilated patients: prospective evaluation of diagnostic accuracy using histology as a diagnostic gold standard. Am J Respir Crit Care Med 1995, 151:1878-1888.

13. Meduri GU, Mauldin GL, Wunderink RG, Leeper KV Jr., Jones CB, Tolley E, Mayhall G: Causes of fever and pulmonary densities in patients with clinical manifestations of ventilator-associated pneumonia. Chest 1994, 106:221-235.

14. Klompas M, Platt R: Ventilator-associated pneumonia-the wrong quality measure for benchmarking. Ann Intern Med 2007, 147:803-805.

15. Klompas $M$ : Does this patient have ventilator-associated pneumonia? JAMA 2007, 297:1583-1593.

16. Papazian L, Thomas P, Garbe L, Guignon I, Thirion X, Charrel J, Bollet C, Fuentes P, Gouin F: Bronchoscopic or blind sampling techniques for the diagnosis of ventilator-associated pneumonia. Am J Respir Crit Care Med 1995, 152(6 Pt 1):19821991.

17. Fabregas N, Ewig S, Torres A, El-Ebiary M, Ramirez J, de La Bellacasa JP, Bauer T, Cabello H: Clinical diagnosis of ventilator associated pneumonia revisited: comparative validation using immediate post-mortem lung biopsies. Thorax 1999, 54:867873.

18. Torres A, el-Ebiary M, Padro L, Gonzalez J, de la Bellacasa JP, Ramirez J, Xaubet A, Ferrer M, Rodriguez-Roisin R: Validation of different techniques for the diagnosis of ventilator-associated pneumonia. Comparison with immediate postmortem pulmonary biopsy. Am J Respir Crit Care Med 1994, 149(2 Pt 1): 324-331.

19. Kirtland $\mathrm{SH}$, Corley DE, Winterbauer RH, Springmeyer SC, Casey $\mathrm{KR}$, Hampson NB, Dreis DF: The diagnosis of ventilator-associated pneumonia: a comparison of histologic, microbiologic, and clinical criteria. Chest 1997, 112:445-457.

20. Singh N, Rogers P, Atwood CW, Wagener MM, Yu VL: Shortcourse empiric antibiotic therapy for patients with pulmonary infiltrates in the intensive care unit. A proposed solution for indiscriminate antibiotic prescription. Am J Respir Crit Care Med 2000, 162(2 Pt 1):505-511.

21. Micek ST, Ward S, Fraser VJ, Kollef MH: A randomized controlled trial of an antibiotic discontinuation policy for clinically suspected ventilator-associated pneumonia. Chest 2004, 125: 1791-1799.

22. Kollef MH, Morrow LE, Niederman MS, Leeper KV, Anzueto A, Benz-Scott L, Rodino FJ: Clinical characteristics and treatment patterns among patients with ventilator-associated pneumonia. Chest 2006, 129:1210-1218.

23. Papazian L, Bregeon F, Thirion X, Gregoire R, Saux P, Denis JP, Perin G, Charrel J, Dumon JF, Affray JP, Gouin F: Effect of ventilator-associated pneumonia on mortality and morbidity. $\mathrm{Am} J$ Respir Crit Care Med 1996, 154:91-97.

24. Heyland DK, Cook DJ, Griffith L, Keenan SP, Brun-Buisson C: The attributable morbidity and mortality of ventilator-associated pneumonia in the critically ill patient. The Canadian Critical Trials Group. Am J Respir Crit Care Med 1999, 159(4 Pt 1): 1249-1256.

25. Rello J, Ollendorf DA, Oster G, Vera-Llonch M, Bellm L, Redman $\mathrm{R}$, Kollef $\mathrm{MH}$ : Epidemiology and outcomes of ventilator-associated pneumonia in a large US database. Chest 2002, 122: 2115-2121.
26. Baker AM, Meredith JW, Haponik EF: Pneumonia in intubated trauma patients. Microbiology and outcomes. Am J Respir Crit Care Med 1996, 153:343-349.

27. Bercault N, Boulain T: Mortality rate attributable to ventilatorassociated nosocomial pneumonia in an adult intensive care unit: a prospective case-control study. Crit Care Med 2001, 29:2303-2309.

28. Cunnion KM, Weber DJ, Broadhead WE, Hanson LC, Pieper CF, Rutala WA: Risk factors for nosocomial pneumonia: comparing adult critical-care populations. Am J Respir Crit Care Med 1996, 153:158-162.

29. Fagon JY, Chastre J, Hance AJ, Montravers P, Novara A, Gibert C: Nosocomial pneumonia in ventilated patients: a cohort study evaluating attributable mortality and hospital stay. $\mathrm{Am} \mathrm{J} \mathrm{Med}$ 1993, 94:281-288.

30. Coffin SE, Klompas M, Classen D, Arias KM, Podgorny K, Anderson DJ, Burstin H, Calfee DP, Dubberke ER, Fraser V, Gerding DN, Griffin FA, Gross P, Kaye KS, Lo E, Marschall J, Mermel LA, Nicolle L, Pegues DA, Perl TM, Saint S, Salgado CD, Weinstein RA, Wise R, Yokoe DS: Strategies to prevent ventilator-associated pneumonia in acute care hospitals. Infect Control Hosp Epidemiol 2008, 29 Suppl 1:S31-40.

31. de Smet AM, Kluytmans JA, Cooper BS, Mascini EM, Benus RF, van der Werf TS, van der Hoeven JG, Pickkers P, BogaersHofman D, van der Meer NJ, Bernards AT, Kuijper EJ, Joore JC Leverstein-van Hall MA, Bindels AJ, Jansz AR, Wesselink RM, de Jongh BM, Dennesen PJ, van Asselt GJ, te Velde LF, Frenay IH, Kaasjager K, Bosch FH, van Iterson M, Thijsen SF, Kluge GH, Pauw W, de Vries JW, Kaan JA, et al.: Decontamination of the digestive tract and oropharynx in ICU patients. $N$ Engl J Med 2009, 360:20-31.

32. Marelich GP, Murin S, Battistella F, Inciardi J, Vierra T, Roby M: Protocol weaning of mechanical ventilation in medical and surgical patients by respiratory care practitioners and nurses: effect on weaning time and incidence of ventilator-associated pneumonia. Chest 2000, 118:459-467.

33. Kollef MH, Shapiro SD, Silver P, St John RE, Prentice D, Sauer S, Ahrens TS, Shannon W, Baker-Clinkscale D: A randomized, controlled trial of protocol-directed versus physician-directed weaning from mechanical ventilation. Crit Care Med 1997, 25: 567-574.

34. Ely EW, Baker AM, Dunagan DP, Burke HL, Smith AC, Kelly PT, Johnson MM, Browder RW, Bowton DL, Haponik EF: Effect on the duration of mechanical ventilation of identifying patients capable of breathing spontaneously. N Engl J Med 1996, 335: 1864-1869.

35. Esteban A, Frutos F, Tobin MJ, Alía I, Solsona JF, Valverdú I, Fernández $\mathrm{R}$, de la Cal MA, Benito $\mathrm{S}$, Tomás $\mathrm{R}$, Carriedo $\mathrm{D}$, Macías S, Blanco J, for The Spanish Lung Failure Collaborative Group: A comparison of four methods of weaning patients from mechanical ventilation. Spanish Lung Failure Collaborative Group. N Engl J Med 1995, 332:345-350.

36. Lellouche F, Mancebo J, Jolliet P, Roeseler J, Schortgen F, Dojat M, Cabello B, Bouadma L, Rodriguez P, Maggiore S, Reynaert M, Mersmann S, Brochard L: A multicenter randomized trial of computer-driven protocolized weaning from mechanical ventilation. Am J Respir Crit Care Med 2006, 174:894-900.

37. Kress JP, Pohlman AS, O'Connor MF, Hall JB: Daily interruption of sedative infusions in critically ill patients undergoing mechanical ventilation. N Engl J Med 2000, 342:1471-1477.

38. Girard TD, Kress JP, Fuchs BD, Thomason JW, Schweickert WD, Pun BT, Taichman DB, Dunn JG, Pohlman AS, Kinniry PA, Jackson JC, Canonico AE, Light RW, Shintani AK, Thompson JL, Gordon SM, Hall JB, Dittus RS, Bernard GR, Ely EW: Efficacy and safety of a paired sedation and ventilator weaning protocol for mechanically ventilated patients in intensive care (Awakening and Breathing Controlled trial): a randomised controlled trial. Lancet 2008, 371:126-134.

39. Bouza E, Perez MJ, Munoz P, Rincon C, Barrio JM, Hortal J: Continuous aspiration of subglottic secretions in the prevention of ventilator-associated pneumonia in the postoperative period of major heart surgery. Chest 2008, 134:938-946.

40. DeRiso AJ 2nd, Ladowski JS, Dillon TA, Justice JW, Peterson AC: Chlorhexidine gluconate $0.12 \%$ oral rinse reduces the incidence of total nosocomial respiratory infection and nonprophylactic systemic antibiotic use in patients undergoing heart surgery. Chest 1996, 109:1556-1561. 
41. Crunden E, Boyce C, Woodman H, Bray B: An evaluation of the impact of the ventilator care bundle. Nurs Crit Care 2005, 10: 242-246.

42. Burger CD, Resar RK: 'Ventilator bundle' approach to prevention of ventilator-associated pneumonia. Mayo Clin Proc 2006, 81:849-850

43. Berriel-Cass D, Adkins FW, Jones P, Fakih MG: Eliminating nosocomial infections at Ascension Health. Jt Comm J Qual Patient Saf 2006, 32:612-620.

44. Lansford T, Moncure M, Carlton E, Endress R, Shik N, Udobi K, Braxton C, Danks R: Efficacy of a pneumonia prevention proto$\mathrm{col}$ in the reduction of ventilator-associated pneumonia in trauma patients. Surg Infect (Larchmt) 2007, 8:505-510.

45. Zilberberg MD, Shorr AF, Kollef $\mathrm{MH}$ : Implementing quality improvements in the intensive care unit: ventilator bundle as an example. Crit Care Med 2009, 37:305-309.

46. van Nieuwenhoven CA, Vandenbroucke-Grauls $\mathrm{C}$, van Tiel FH, Joore HC, van Schijndel RJ, van der Tweel I, Ramsay G, Bonten MJ: Feasibility and effects of the semirecumbent position to prevent ventilator-associated pneumonia: a randomized study. Crit Care Med 2006, 34:396-402.

47. Houston S, Hougland P, Anderson JJ, LaRocco M, Kennedy V, Gentry LO: Effectiveness of $0.12 \%$ chlorhexidine gluconate oral rinse in reducing prevalence of nosocomial pneumonia in patients undergoing heart surgery. Am J Crit Care 2002, 11: 567-570.

48. Fourrier $F$, Dubois $D$, Pronnier $P$, Herbecq $P$, Leroy $O$, Desmettre T, Pottier-Cau E, Boutigny H, Di Pompéo C, Durocher A, RousselDelvallez M; PIRAD Study Group: Effect of gingival and dental plaque antiseptic decontamination on nosocomial infections acquired in the intensive care unit: a double-blind placebocontrolled multicenter study. Crit Care Med 2005, 33:17281735.

49. Segers $P$, Speekenbrink RG, Ubbink DT, van Ogtrop ML, de Mol BA: Prevention of nosocomial infection in cardiac surgery by decontamination of the nasopharynx and oropharynx with chlorhexidine gluconate: a randomized controlled trial. JAMA 2006, 296:2460-2466.

50. Tantipong $\mathrm{H}$, Morkchareonpong $\mathrm{C}$, Jaiyindee $\mathrm{S}$, Thamlikitkul V: Randomized controlled trial and meta-analysis of oral decontamination with $2 \%$ chlorhexidine solution for the prevention of ventilator-associated pneumonia. Infect Control Hosp Epidemio/ 2008, 29:131-136.

51. Laggner AN, Tryba M, Georgopoulos A, Lenz K, Grimm G, Graninger W, Schneeweiss B, Druml W: Oropharyngeal decontamination with gentamicin for long-term ventilated patients on stress ulcer prophylaxis with sucralfate? Wien Klin Wochenschr 1994, 106:15-19.

52. Bergmans DC, Bonten MJ, Gaillard CA, Paling JC, van der Geest $\mathrm{S}$, van Tiel FH, Beysens AJ, de Leeuw PW, Stobberingh EE: Prevention of ventilator-associated pneumonia by oral decontamination: a prospective, randomized, double-blind, placebocontrolled study. Am J Respir Crit Care Med 2001, 164: 382-388.

53. Kollef M, Pittet D, Sánchez García M, Chastre J, Fagon JY, Bonten M, Hyzy R, Fleming TR, Fuchs $\mathrm{H}$, Bellm L, Mercat A, Mañez R, Martínez A, Eggimann $P$, Daguerre M, Luyt CE; Prevention of Pneumonia Study (POPS-1) Trial Group: A randomized doubleblind trial of iseganan in prevention of ventilator-associated pneumonia. Am J Respir Crit Care Med 2006, 173:91-97.

54. Samama MM, Cohen AT, Darmon JY, Desjardins L Eldor A, Janbon C, Leizorovicz A, Nguyen H, Olsson CG, Turpie AG, Weisslinger N: A comparison of enoxaparin with placebo for the prevention of venous thromboembolism in acutely ill medical patients. Prophylaxis in Medical Patients with Enoxaparin Study Group. N Engl J Med 1999, 341:793-800.

55. Fraisse F, Holzapfel L, Couland JM, Simonneau G, Bedock B, Feissel M, Herbecq P, Pordes R, Poussel JF, Roux L: Nadroparin in the prevention of deep vein thrombosis in acute decompensated COPD. The Association of Non-University Affiliated Intensive Care Specialist Physicians of France. Am J Respir Crit Care Med 2000, 161(4 Pt 1):1109-1114.

56. Leizorovicz A, Cohen AT, Turpie AG, Olsson CG, Vaitkus PT, Goldhaber SZ: Randomized, placebo-controlled trial of dalteparin for the prevention of venous thromboembolism in acutely ill medical patients. Circulation 2004, 110:874-879.

57. Mahé I, Bergmann JF, d'Azémar P, Vaissie JJ, Caulin C: Lack of effect of a low-molecular-weight heparin (nadroparin) on mortality in bedridden medical in-patients: a prospective randomised double-blind study. Eur J Clin Pharmacol 2005, 61: 347-351

58. Prod'hom G, Leuenberger P, Koerfer J, Blum A, Chiolero R Schaller MD, Perret C, Spinnler O, Blondel J, Siegrist H, Saghafi L, Blanc D, Francioli P: Nosocomial pneumonia in mechanically ventilated patients receiving antacid, ranitidine, or sucralfate as prophylaxis for stress ulcer. A randomized controlled trial. Ann Intern Med 1994, 120:653-662.

59. Bonten MJ, Gaillard CA, van der Geest S, van Tiel FH, Beysens AJ, Smeets HG, Stobberingh EE: The role of intragastric acidity and stress ulcus prophylaxis on colonization and infection in mechanically ventilated ICU patients. A stratified, randomized, double-blind study of sucralfate versus antacids. Am J Respir Crit Care Med 1995, 152(6 Pt 1):1825-1834.

60. Yildizdas D, Yapicioglu H, Yilmaz HL: Occurrence of ventilatorassociated pneumonia in mechanically ventilated pediatric intensive care patients during stress ulcer prophylaxis with sucralfate, ranitidine, and omeprazole. J Crit Care 2002, 17: 240-245

61. Kantorova I, Svoboda P, Scheer P, Doubek J, Rehorkova D Bosakova H, Ochmann J: Stress ulcer prophylaxis in critically ill patients: a randomized controlled trial. Hepato-gastroenterology 2004, 51:757-761.

62. Kollef MH, Skubas NJ, Sundt TM: A randomized clinical trial of continuous aspiration of subglottic secretions in cardiac surgery patients. Chest 1999, 116:1339-1346.

63. Smulders K, van der Hoeven H, Weers-Pothoff I, VandenbrouckeGrauls C: A randomized clinical trial of intermittent subglottic secretion drainage in patients receiving mechanical ventilation. Chest 2002, 121:858-862.

64. Lorente L, Lecuona M, Jimenez A, Mora ML, Sierra A: Influence of an endotracheal tube with polyurethane cuff and subglottic secretion drainage on pneumonia. Am J Respir Crit Care Med 2007, 176:1079-1083.

65. Schweickert WD, Gehlbach BK, Pohlman AS, Hall JB, Kress JP: Daily interruption of sedative infusions and complications of critical illness in mechanically ventilated patients. Crit Care Med 2004, 32:1272-1276. 